\title{
ASIC2 wt Allele
}

National Cancer Institute

\section{Source}

National Cancer Institute. ASIC2 wt Allele. NCI Thesaurus. Code C114693.

Human ASIC2 wild-type allele is located in the vicinity of $17 q 12$ and is approximately 1162 $\mathrm{kb}$ in length. This allele, which encodes acid-sensing ion channel 2 protein, plays a role in the modulation of membrane potential through proton-gated cation transport. 